\title{
Advancing Preservice Physics Teachers' Critical Thinking through Active and Passive Microteaching Lesson Study
}

\author{
Billy A. Danday \\ Leyte Normal University, Tacloban City, Philippines \\ https://orcid.org/0000-0002-9771-5912
}

\begin{abstract}
A pretest-posttest comparison-group quasi-experimental study was endeavoured to unravel the effects of the two forms of Microteaching Lesson Study (MLS), the Active MLS and the Passive MLS, on the critical thinking of aspiring physics teachers. Eighteen Bachelor of Secondary Education specializing in Physical Science students participated in the six-week study. Data were gathered using the Critical Thinking Inventory in Physics and were analysed utilizing the Wilcoxon Signed Ranks Test, Mann-Whitney U Test, and descriptive statistics. Results revealed that both the Active and Passive MLS have positive effects on the overall critical thinking and on all of the critical thinking sub-skills of the preservice teachers. Results further showed that the Active MLS is significantly more effective than the Passive MLS in developing overall critical thinking and its sub-skills, specifically, inference and interpretation. The implementation of lessons by the Active MLS group in microteaching sessions indicated positive affordances on the development of critical thinking. Further studies involving a greater number of preservice teachers specializing in different fields of science are recommended. The integration of the MLS, especially the Active MLS, in the preservice teaching curricula is deemed a worthwhile engagement.
\end{abstract}

Keywords: critical thinking; lesson study (LS); microteaching; physics teaching; preservice teachers

\section{Introduction}

The world is currently facing insurmountable challenges - climate change, environmental degradation, political conflicts, depletion of resources, and pandemics, among others. Humans around the globe are constantly challenged to act efficiently and effectively for sustainable existence. These, apparently, require critical thinking considering that effective actions demand critical scrutiny of problems at hand (Buckley, 2012; Sensibaugh, 2015; Tseng, 2008; Williams, 2005). Educational institutions are commissioned to proliferate learning; hence, curricular programmes need to inculcate critical thinking among learners, be it in the sciences or the arts, if sustainable existence is aspired (Nilson et al., 2013). 
Teaching critical thinking is supposed to emanate from teacher education institutions. Preservice teachers' primary interest should be to possess good critical thinking dispositions and to acquire critical thinking skills for continued proliferation of analytical and systematic reasoning and problem-solving (Arsal, 2015). Studies, nevertheless, disclose a dismal level of critical thinking among preservice teachers (Akdere, 2012; Grosser \& Nel, 2013; Qing et al., 2010). Aspiring teachers often hold an inadequate perception of critical thinking and its fundamental skills, particularly regarding its application in classroom activities (Gashan, 2015; Meister, 2011). They even were unclear about the associations between learning objectives and assessment of teaching outcomes (Cavanagh et al., 2019). This alarming deficiency requires immediate and profound interventions; hence, scholars launched various initiatives to address this deficit. However, varied strategies did not generate consistent positive outcomes (Akyuz \& Samsa, 2009; Behar-Horenstein \& Niu, 2011; Goyak, 2009; Qing et al., 2010; Sulaiman, 2013). Therefore, further exploration of didactic approaches that support the development of critical thinking in future teachers is urgently required.

The conventional, individualistic instructional approach, which is extensively employed in preservice teacher education curricula, particularly in the practicum stage, seems to lack opportunities to scaffold critical thinking skills. Perspectives from collaborative instructional approaches, like the Lesson Study, are worth pursuing, due to the various interactions that the instructional approach demands from participants (Chen \& Zhang, 2019; Chew \& Lim, 2013; Elipane, 2012). A microteaching-based Lesson Study framework can be especially engaging, because microteaching does not only bring the prospective teachers to an actual classroom setting but it also strengthens their professional competence (Akkus \& Uner, 2017; Remesh, 2013; Sentumbwe, 2018, Zhou \& Xu, 2017).

While a few studies have accounted for the effects of Microteaching Lesson Study on some aspects of student learning, little or nothing is known about the effects of the active and passive versions of Microteaching Lesson Study on preservice teachers' critical thinking. This study has been designed to explore salient influences of two forms of this instructional approach on overall critical thinking and its specific components in the domain of physics instruction. Specifically, the study was aimed at answering the following questions:

(1) Do the active MLS and passive MLS approaches render significantly higher critical thinking scores in the post-test than in the pre-test?

(2) Is there a significant difference between the critical thinking scores of the active MLS group and passive MLS group after the intervention?

(3) What are the benefits of active and passive MLS in the development of critical thinking? 


\section{Related Literature}

\subsection{Lesson Study}

Japan has long been on the upper stratum and continues to be one of the leading countries in terms of performance in the Trends in Mathematics and Science Study (TIMSS), alongside with Singapore and other Asian countries. The Japanese educational system is undeniably one of the better systems in the world that is worthy of emulation. It is not surprising that one of their most effective professional development programmes, the jugyokenkyu or the lesson study (Figure 1), is extensively adopted by educational institutions around the world (Buchard \& Martin, 2017; Cerbin \& Kopp, 2006; Chen \& Zhang, 2019; Fernandez, 2002; Lewis et al., 2009; Zhou \& Xu, 2017).

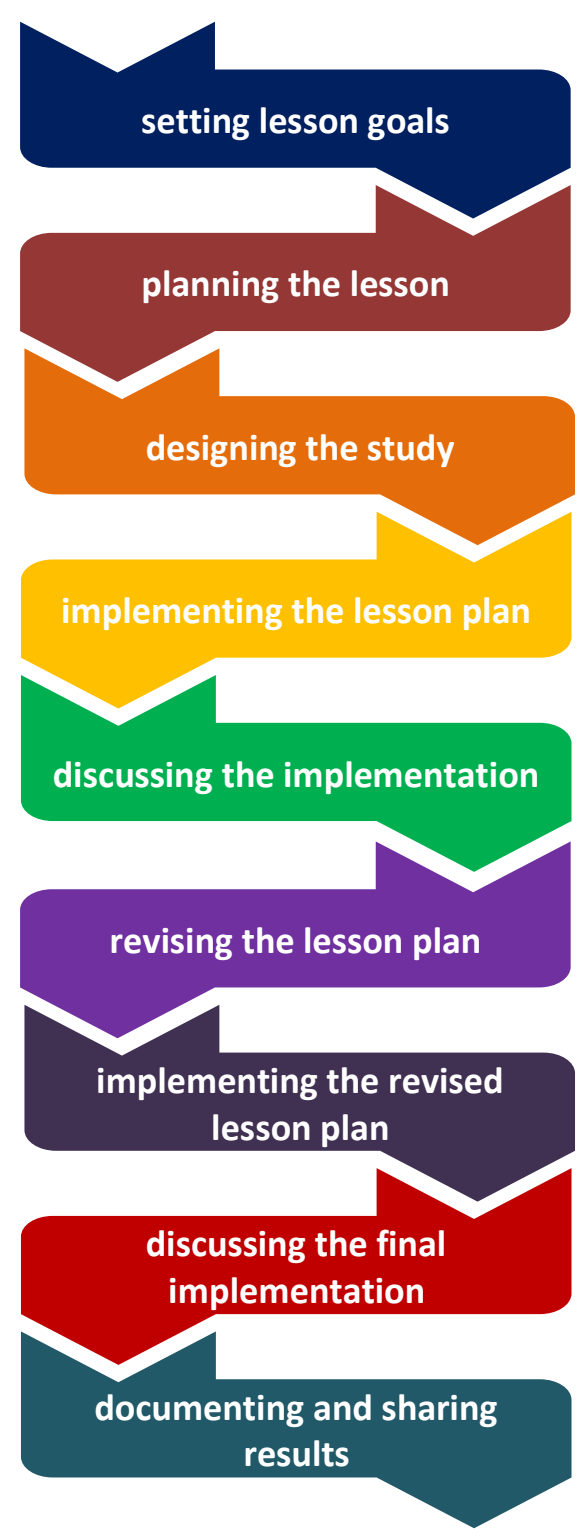

Figure 1: The Lesson Study Process

"Jugyo" is the Japanese term for lesson while "kenkyu" refers to study, hence, Lesson Study is the literal English translation of the two Japanese words 
(Fernandez, 2002). Lesson Study is an in-service professional development approach for teachers that is distinguished due to its collaborative nature. It has fascinated countless educators of various disciplines, particularly those who have been oriented according to the individualistic instructional approach.

The Lesson Study (LS) process possesses the following features: investigation, planning, research lesson, and reflection (Lewis et al., 2009). An extensive examination of the various adaptations of the Lesson Study shows the following procedure: (1) setting lesson goals, (2) planning the lesson, (3) devising the study, (4) executing the lesson plan, (5) deliberating on the implementation, (6) modifying the lesson plan, (7) executing the revised lesson plan, (8) deliberating on the implementation of the new version of the lesson plan, and (9) documenting and sharing results (Cavin, 2007; Cerbin \& Kopp, 2006; Chew \& Lim, 2013; Fernandez, 2002). Figure 1 illustrates the complete procedure of the Lesson Study model as implemented by diverse scholars.

It must be noted that the Lesson Study members are three or more teachers working together throughout the whole process. External experts are often invited to observe the lesson implementations and take part in the analyses of the data gathered (Lewis et al., 2006). Meanwhile, Cerbin and Kopp (2006) point out that lesson studies are intended to examine how students learn the lessons, not to assess what students have learned. The analysis of the interactions among students, teachers, and instructional aids is the heart of the Lesson Study framework.

Research has revealed various benefits of the Lesson Study to in-service teachers, preservice teachers, and students. This professional development approach can enhance teachers' content knowledge, pedagogical skills, and didactic beliefs (Danday, 2019; Lewis et al., 2009). Moreover, LS fosters group ownership, collegial support, instructional expertise, teaching confidence, and a better understanding of students' thinking (Barrett et al., 2013; Fernandez, 2002; Kolenda, 2007; Lewis, 2002).

Similar findings have been reported on the integration of Lesson Study into preservice teacher education. Elipane (2012) and Gurl (2009) reported that LS has the potential of improving teaching skills, habits, and competencies. Furthermore, engaging in the Lesson Study can broaden the Nature of Science (NOS) pedagogical content knowledge of preservice teachers and can successfully transform it into classroom praxis (McDowell, 2010).

Lesson Study also has shown positive influences on the learners. Barrett et al. (2013) reported that the students whose teachers had been in the Lesson Study groups performed significantly better in geometry than the students whose teachers had been in the traditional setting. Similarly, Lucenario et al. (2016) reported that a Pedagogical Content Knowledge-Guided Lesson Study (PCKLS) for chemistry teachers improved students' problem-solving skills. Teele et al. (2015) also noted that exposure to Lesson Study-based instruction had a positive impact on students' achievement in mathematics. 
Integrating technology in the Lesson Study framework has offered more interesting outcomes. Chew and Lim (2013) found that employing Lesson Study (LS) with the use of Geometer's Sketchpad (GSP) in teaching mathematics could enhance the technological pedagogical content knowledge of preservice teachers. According to Cavin (2007) a Microteaching Lesson Study (MLS) can generate a positive learning atmosphere, ensuing in the appreciation of technology integration into learner-centred instruction.

Apart from classroom instruction, lesson study also may serve as an effective vehicle for curriculum design, implementation, and assessment. For instance, Gutierez (2015) utilized the Lesson Study model to identify the issues associated with the implementation of inquiry-based instruction in elementary science in the Philippines. She emphasised three key issues: (1) scarcity of inquiry-based resources and lack of professional support; (2) emphasis on content learning, rather than inquiry-learning; and (3) the time-consuming and laborious nature of inquiry-based pedagogies.

From the above discussion it is clear that literature provides a satisfactory elucidation of the Lesson Study framework. However, a gap still exists in knowledge about characterizing active and passive forms of microteaching lesson study, and the corresponding effects on preservice teachers' critical thinking skills and sub-skills. The author, hence, deemed it imperative to investigate these domains to cast broader light on this instructional approach in the field of physics education.

\subsection{Critical Thinking}

One of the primary goals of global education is for learners to attain critical thinking skills. The 21st century learning framework establishes the skills that modern-day learners should possess. Education experts agree that learners should acquire life and career skills, learning and innovation skills, and information, media, and technology skills from all corners of educational institutions. In the learning and innovation skills domain, critical thinking is a priority goal, along with communication, collaboration, and creativity (Battelle for Kids, 2019). The curricula for science and all other subject areas, therefore, are aimed towards the attainment of these goals.

Edward Glaser (1941) identified three facets of critical thinking - the attitude of insightful thinking, the knowledge of systematic reasoning and analytical methods, and the skill to employ such methods. The American Philosophical Association (APA) Delphi Consensus expresses the contention of the critical thinking experts on the definition of the term. They assert that critical thinking is "the purposeful, self-regulatory judgment which results in interpretation, analysis, evaluation, and inference, as well as explanation of the evidential, conceptual, methodological, criteriological, or contextual considerations upon which that judgment is based" (Facione, 1998). 


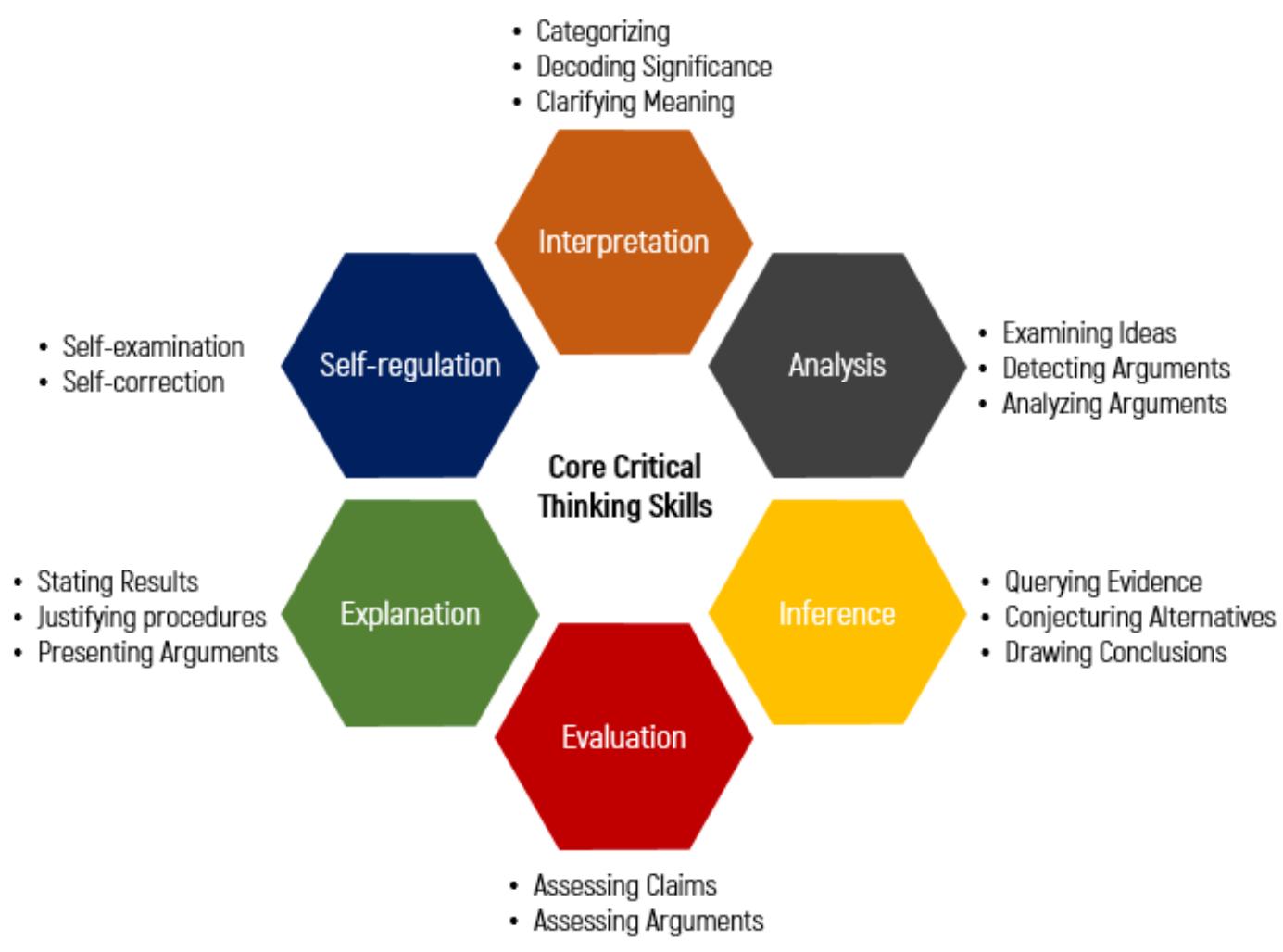

Figure 2: The Core Critical Thinking Skills and Sub-skills

To place critical thinking in a well-defined context, scholars have posited interpretation, analysis, inference, evaluation, explanation, and self-regulation as the core critical thinking skills, with specific competencies indicating each skill. This opens the construct for observation, measurement, and validation. Figure 2 captures the critical thinking construct at one glance.

The acquisition of satisfactory levels of all the critical thinking skills is the embodiment of an ideal critical thinker. Experts, however, concur that a critical thinker may not necessarily possess a high level of all the aforementioned skills. One may be proficient at some skills but may not be at other skills (Facione, 2020).

Measuring critical thinking has been a crucial step in expanding this body of knowledge. Experts have developed well-crafted and standardized instruments to quantify critical thinking in formal/non-formal education and career assessments. Based on content and features, these instruments have been categorized into (1) general-content, multi-aspect; (2) general-content, aspectspecific; and (3) subject-specific, multi-aspect critical thinking tests (Ennis, 2009). The investigations of critical thinking in higher education have shown a dominant utilization of the Watson-Glaser Critical Thinking Appraisal (WGCTA), California Critical Thinking Skills Test (CCTST), and Cornell Critical Thinking Tests (CCTT), all of which are classified under general-content, multi-aspect instruments (BeharHorenstein \& Niu, 2011).

Meanwhile, research has shown that the Watson-Glaser Critical Thinking Appraisal (WGCTA) is aptly applicable in measuring the critical thinking of 
preservice teachers. Gadzella et al. (2005) used the Short Form (Form-S) of this measurement instrument in their investigation and confirmed its suitability for teacher education. The instrument measures five critical-thinking skills, namely inference, recognition of assumptions, deduction, interpretation, and evaluation of arguments (Behar-Horenstein \& Niu, 2011). With reference to the APA Delphi Consensus, the WGCTA does not contain explanation, analysis, and selfregulation as principal critical-thinking skills; however, it includes recognition of assumptions and deduction. Scholars in various fields, though, recognize its applicability and effectiveness in assessing the critical thinking of students, employees, and other adult participants (Behar-Horenstein \& Niu, 2011; Ennis, 2009; Grosser \& Nel, 2013).

Some scholars argue that the assessment of critical thinking can be done not only quantitatively, but qualitatively as well; they posit that certain aspects of the quality of thinking need not be captured by quantitative methods. Facione and Facione (2011), for example, developed the Holistic Critical Thinking Scoring Rubric (HCTSR) to evaluate thinking expressed as verbal and written accounts. . This scoring rubric consists of explicit qualitative descriptions with an associated numerical value which may be used in various assessments such as in training programmes and other educational engagements. This contention motivated the author to utilize both quantitative and qualitative measurement of critical thinking of the preservice teachers who participated in the study, employing a physics-oriented critical thinking instrument and a modified HCTSR.

Behar-Horenstein and Niu (2011) established the dominance of quasiexperimental pretest-posttest design studies on critical thinking in higher education. They also found that the majority of the studies conducted had been executed in the field of medical education. Among the instructional strategies that had been investigated were concept mapping, scenario-based course exercises, active learning techniques, online instruction, inquiry-based learning, guided practice, computer-assisted instruction, structured web-based bulletin boards, and problem-based learning. The results of these studies generated mixed impressions; no single instructional method was shown to either be always effective or ineffective.

Few studies have been undertaken investigating critical thinking levels and pedagogical methods with the potential of effecting the critical thinking of preservice teachers. One such study (Akdere, 2012) found a 'below average' level of critical thinking among Turkish preservice teachers. Such a finding was unexpected, considering that the same participants had a moderately positive attitude towards critical thinking (Akdere, 2012). A similar observation was claimed by Qing et al. (2010). The Chinese preservice teachers who participated in their study showed a low level of critical thinking prior to their engagement in the inquiry-based chemical experiment. The same level of performance was observed even after their exposure to the pedagogical approach.

Tican and Taspinar (2015), likewise, reported that preservice teachers who had been exposed to reflective thinking-oriented didactic activities had critical 
thinking skills comparable to those who were exposed to traditional teaching methods. No significant statistical difference was found between the two groups.

On the other hand, Jatmiko et al. (2018) and Sulaiman (2013) probed the effects of the Problem-Based Learning (PBL) model on the critical thinking of preservice physics and preservice science teachers, respectively. Jatmiko et al. employed the conventional PBL model with 94 participants, while Sulaiman employed the PBL Online with 41 participants. Jatmiko et al. reported positive effects of the PBL on the critical thinking of the preservice physics teachers using the Student Critical Thinking Skills Test. Meanwhile, employing the WGCTA Forms A and B, Sulaiman found a non-significant difference in the critical thinking of the PBL group and the traditional group after the intervention, notwithstanding the significantly better performance of the PBL group than the traditional group in creativity.

In an attempt to assess the efforts to enhance critical thinking of undergraduate college students, a recent study has been conducted by investigating 4,000 participants. It was found that the 2,000 randomly selected undergraduate college students in 2019 scored significantly higher in the California Critical Thinking Skills Test (CCTST) than the 2,000 randomly selected students at the same level who took the same test in 2012 (Facione et al., 2020). The result implies that educational efforts strived for the development of critical thinking among learners in higher education have paid off. This implies that a sustained fortitude may eventually build communities of critical thinkers.

It can be assumed that the critical thinking construct in the preservice teacher education domain remains to be cultivated. A plethora of didactic innovations yet have to be forged, particularly collaborative and learner-centred pedagogical approaches. One such approach is the Microteaching Lesson Study that offers potential advances in various facets of learning. Its effects on preservice teachers' critical thinking, using both quantitative and qualitative methods, still are unexplored, especially during active and passive forms of microteaching. Moreover, little is known about research on critical thinking utilizing contentbased assessment tools, especially in physics education. These motivations propelled the researcher to undertake the present study.

\section{Methodology}

\subsection{Research Design}

A pretest-posttest comparison-group quasi-experimental design was employed in this study. Two groups were formed from a class of fourth-year level college students in the Bachelor of Secondary Education (BSED) programme specializing in Physical Science. Nine participants were randomly chosen for each group - the Active MLS Group and the Passive MLS Group - through a simple fishbowl technique. Each of these groups was divided further into three sub-groups with three members each. Figure 3 exemplifies the formation of the Active MLS and Passive MLS sub-groups. 


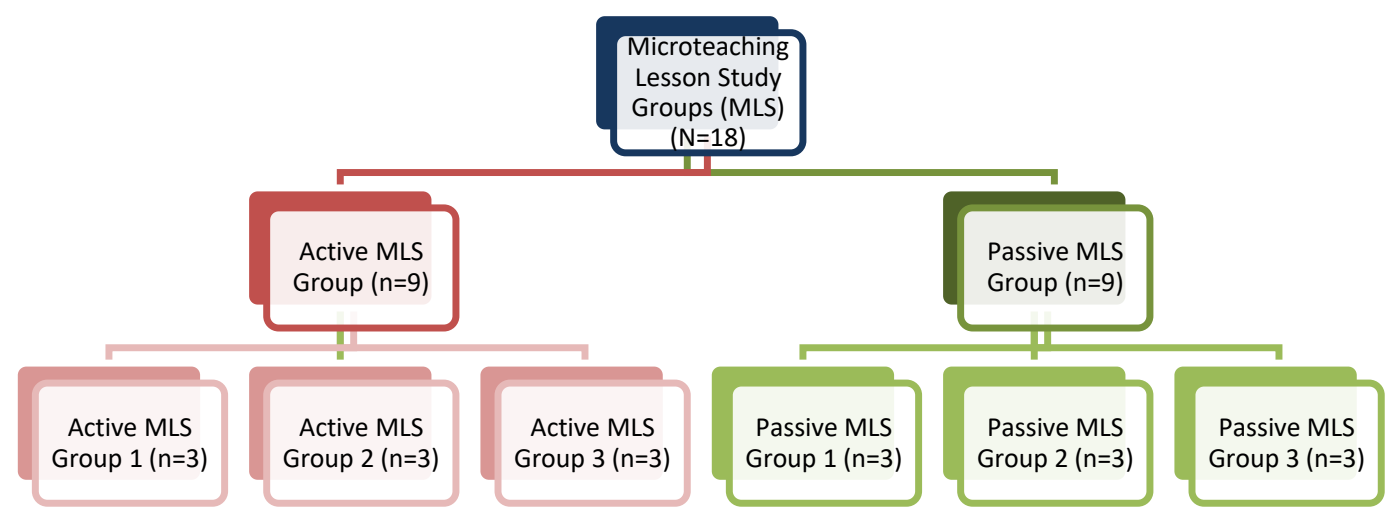

Figure 3: The formation of the Active MLS and the Passive MLS sub-groups

In adherence to ethical standards set by the university for social science research, an informed consent form was required to be completed by the research participants to declare their voluntary participation in the study and free will to withdraw anytime during the course of the study. Based on Philippine law, none of the participants were under age since all of them were 18 years old and above. Moreover, none of them withdrew from participating in the study.

The data collection procedure for this study phase lasted for six weeks, and it was conducted at a state university during the summer term of the school year 20162017. It commenced with orientating the subject teacher and research participants to the research procedure. The pre-test for critical thinking was administered a day before the intervention was conducted. During the succeeding weeks the nine preservice teachers were exposed to the Active MLS and the other nine to the Passive MLS. The post-test was administered on the last day of the six-week intervention.

The researcher guided the subject teacher throughout the data-collection process. He assisted the teacher in assessing the participants' instructional plans and materials. He also took part in the microteaching sessions and post-lesson discussions. The researcher acted the role of an external expert and facilitator in the Lesson Study model.

\section{The Active and Passive Microteaching Lesson Study}

The research intervention utilized the lesson study (LS) framework through microteaching sessions. In-service lesson study engagements involve actual lesson implementations in classes handled by the teachers in the LS group. It must be noted that in this study the research participants implemented their lesson plans with their classmates serving as "students".

It must also be clear that only the active MLS group members implemented their lesson plans. One group was assigned to teach per microteaching session. The passive MLS group participated in the microteaching sessions by acting as "students" together with the non-teaching active MLS group for the session. 
Nine grade 8 science lessons in physics were covered for the study. The areas included were dynamics, heat and thermodynamics, electricity and magnetism, waves, and optics. Three instructional plans and teaching materials had been prepared by each sub-group, and they shared these with other sub-groups within their respective group at the end of the research intervention. For instance, the outputs of Group 1 were shared with the other two sub-groups in the active MLS group only. The same process was followed by the passive MLS sub-groups.

Table 1: The Active MLS and Passive MLS procedures

\begin{tabular}{|c|c|}
\hline Active MLS & Passive MLS \\
\hline 1. Identifying learning areas & 1. Identifying learning areas \\
\hline 2. Designing the research lesson & 2. Designing the research lesson \\
\hline 3. Investigating the learning process & 3. Investigating the learning process \\
\hline $\begin{array}{l}\text { 4. Implementing the lesson plan } \\
\text { (microteaching) }\end{array}$ & $\begin{array}{l}\text { 4. Acting as "students" in the } \\
\text { microteaching }\end{array}$ \\
\hline $\begin{array}{l}\text { 5. Discussing the results of the } \\
\text { implementation }\end{array}$ & 5. Revisiting the lesson plan \\
\hline 6. Revising the lesson plan & $\begin{array}{l}\text { 6. Revising the lesson plan } \\
\text { (optional) }\end{array}$ \\
\hline $\begin{array}{l}\text { 7. Implementing the revised lesson } \\
\text { plan (microteaching) }\end{array}$ & $\begin{array}{l}\text { 7. Acting as "students" in the } \\
\text { microteaching }\end{array}$ \\
\hline $\begin{array}{l}\text { 8. Discussing the results of the } \\
\text { second implementation }\end{array}$ & $\begin{array}{l}\text { 8. Reassessing the lesson plan } \\
\text { (optional) }\end{array}$ \\
\hline Documenting and sharing results & 9. Documenting and sharing results \\
\hline
\end{tabular}

Table 1 differentiates the MLS processes that were undertaken by the active MLS group and passive MLS group. It can be assumed that all the steps of the Lesson Study Model described in Figure 1 were carried out by all the sub-groups, except that the passive MLS group did not implement its lesson plans. They rather took part in the lesson implementations of the active MLS members by acting as "students" until all the nine lessons had been implemented (Steps 4 and 7).

Post-lesson discussions among the teaching sub-group members of the active MLS group, subject teacher, and researcher were conducted after lesson implementations (Steps 5 and 8). During this stage, the passive MLS sub-groups reviewed their lesson plan to incorporate possible changes based on their observations in the microteaching.

Revision of the instructional plan by the teaching active MLS sub-group followed the post-lesson discussions (Steps 6 and 9). At this time, the passive MLS subgroups had the option of revising their lesson plan (Steps 6 and 8). The final step involved sharing the finalized lesson plan, improved instructional materials, and detailed observations.

\subsection{The Sample}

The research participants were 18 students, specializing in physical science in the Bachelor of Secondary Education (BSED) programme at a state university in Tacloban City, Philippines, with ages ranging from 18 to 22 years. The mean age of the active MLS group was 19.00 years, and 19.72 years for the passive MLS group. 
A total of nine $(50 \%)$ male and nine $(50 \%)$ female preservice teachers participated in the study. The active MLS group comprised three males, that is, 33.3\% of the group sample and six female (66.7\%) participants. Meanwhile, six male or $66.7 \%$ of the group sample and three female $(33.3 \%)$ participants formed the passive MLS group.

\section{Initial Comparability in Academic Performance}

The comparability of the academic performance of the two groups of research participants was established by analysing their respective ratings in the two mathematics and 13 science courses that they had successfully completed prior to their involvement in the study. The mean and median ratings per group were determined and were further analysed using the Mann-Whitney $U$ test through the SPSS Version 23. Results are summarized in Table 2.

Table 2: Data and analysis for the ratings in Science and Mathematics

\begin{tabular}{ccccc}
\hline Subject/Group & $\boldsymbol{N}$ & Mean Rating & Median & $p$ \\
\hline Science & & & & \\
Active MLS & 9 & 1.89 & 1.94 & .863 \\
Passive MLS & 9 & 1.89 & 1.87 & \\
Mathematics & & & & \\
Active MLS & 9 & 1.77 & 1.80 & .489 \\
Passive MLS & 9 & 1.68 & 1.75 & \\
\hline
\end{tabular}

Note: The highest passing mark is 1.00, while the lowest is 3.00 in the university where the study was conducted. It means that the higher the numerical value, the lower is the rating.

Results show that the mean ratings for science were equal between the active MLS and passive MLS group (1.89), although a slightly higher median rating was observed in the passive MLS group (1.87) than in the active MLS group (1.94). A $\mathrm{p}$-value of $\mathrm{p}=.863$ denotes that the academic performance of the two groups in science is not significantly different.

Results further show that the active MLS group had lower mean and median ratings (1.77 and 1.80, respectively) than the passive MLS group (1.68 and 1.75, respectively). However, the statistical analysis reveals that the difference in group ratings was not significant. Hence, it can be affirmed that the active MLS and passive MLS groups are comparable with respect to scholastic performance in the two major academic fields, the sciences and mathematics.

\subsection{The Instruments}

The researcher gathered the data using three instruments as described in the succeeding texts.

\section{A. Preservice Teacher Critical Thinking Inventory in Physics (PTCTI)}

The critical thinking of the research participants was measured through the PTCTI, a physics content-based researcher-made instrument, composed of 60 objective-type and open-ended items. The instrument was modelled on the Watson-Glaser Critical Thinking Appraisal (WGCTA), where 12 items in the 
physics context were crafted for each component - Inference, Recognition of Assumptions, Deduction, Interpretation, and Evaluation of Arguments.

An explanation of the choice of option was required for each objective-type item . While one point was allotted for each correct response to the objective-type items, the explanation was scored based on the descriptions provided in The Holistic Critical Thinking Scoring Rubric by Facione and Facione (2011), which ranged from zero to three. Few modifications were made to the assessment tool to suit the research objectives and context.

The instructions, items, and content of the PTCTI were validated by experts in science and mathematics education whose academic works entail studies into critical thinking development, as well as the production of research instruments and instructional materials that promote critical thinking skills. Meanwhile, the BSED-Physical Science specialists from two state universities were invited to the pilot-testing of the PTCTI. The overall reliability test of the instrument revealed a Cronbach's alpha of .923, as shown in Table 3, signifying its high reliability in critical thinking assessment. Its sub-tests also recorded acceptable reliability levels for social science research, which ranged from .701 to .807 .

Table 3: The SPSS computation of Cronbach's alpha of the PTCTI

\begin{tabular}{|r|r|r|}
\hline $\begin{array}{c}\text { Cronbach's } \\
\text { Alpha }\end{array}$ & $\begin{array}{c}\text { Cronbach's } \\
\text { Alpha Based } \\
\text { on } \\
\text { Standardized } \\
\text { Items }\end{array}$ & N of Items \\
\hline .923 & .926 & 60 \\
\hline
\end{tabular}

\section{B. Interview Protocol}

An interview was conducted on the last day of the intervention. A researchercompiled interview protocol was utilized to substantiate observation notes, postlesson discussions, and quantitative data. The pre-constructed questions revolved around the participants' reflections on the instructional approach to which they were exposed. Follow-up questions were added to illuminate vague ideas or statements as necessary.

\section{Journal}

The participants recorded their observations, learning experiences, and insights in a journal for the entire MLS engagement. The content of the entries was analysed to deduce themes concerning critical thinking development to support the quantitative analyses.

\subsection{Data Analysis Procedure}

The research objectives necessitated the collection of quantitative data that could be illuminated by qualitative data. Descriptive statistics like mean and median were used to depict scores of the research participants in the Preservice Teacher Critical Thinking Inventory in physics (PTCTI). Significant differences between groups were identified by employing the Mann-Whitney U Test, whereas the 
Wilcoxon Signed Ranks Test was utilized to analyse within-group differences. These inferential statistical tests were set at $\alpha=.05$ level of significance.

The researcher employed the conceptual content analysis technique to analyse the qualitative data derived from interview responses, journal entries, and observation notes. Results of the analysis were used to substantiate both quantitative and qualitative findings.

\section{Results}

\subsection{Critical Thinking Prior to the Study.}

A pre-test on the critical thinking of the research participants was administered a day before conducting the intervention. It must be noted that the highest possible score for the Critical Thinking test is 300 points and the lowest is zero.

Table 4 indicates that the active MLS group $(M n=124.00,41.3 \%)$ scored lower than the passive MLS group $(M n=131.44,43.8 \%)$. The same trend was observed when the median scores were examined.

Table 4: Pre-test results for the critical thinking inventory

\begin{tabular}{|c|c|c|c|c|}
\hline Test/Group & $N$ & $M d(\operatorname{Max} .=300)$ & $\begin{array}{c}M n \\
(\operatorname{Max} .=300)\end{array}$ & $S D$ \\
\hline \multicolumn{5}{|l|}{ Pre-test } \\
\hline Active MLS & 9 & $118(39.3 \%)$ & $124.00(41.3 \%)$ & 31.2 \\
\hline Passive MLS & 9 & $130(43.3 \%)$ & $131.44(43.8 \%)$ & 26.2 \\
\hline Total & 18 & $127(42.3 \%)$ & $127.72(42.6 \%)$ & 28.2 \\
\hline
\end{tabular}

Despite the passive MRLS group scoring higher than the active MRLS group, it can be gleaned from Table 5 that the difference in the pre-test group scores is not significant $(p=.627)$, with a low effect size $(r=.11)$. This suggests that the active MLS group and the passive MLS group were comparable before they participated in the study.

Table 5: Mann-Whitney $U$ test of the critical thinking inventory pre-test

\begin{tabular}{ccccccc}
\hline Test/Group & $\boldsymbol{N}$ & $\begin{array}{c}\text { Mean } \\
\text { Rank }\end{array}$ & $\begin{array}{c}\text { Mann- } \\
\text { Whitney } U\end{array}$ & $\mathrm{Z}$ & $\boldsymbol{p}$ & $\boldsymbol{r}(\mathrm{ES})$ \\
\hline $\begin{array}{c}\text { Pre-test } \\
\text { Active MLS }\end{array}$ & 9 & 8.89 & & & & \\
Passive MLS & 9 & 10.11 & 35.0 & -.486 & .627 & .11 \\
\hline
\end{tabular}

Table 6 exhibits the analysis of the pre-test results of the five components of critical thinking. The passive MLS group scored slightly higher in the Inference, Deduction, Interpretation, and Evaluation of Arguments components than the active MLS group. Conversely, the active MLS group scored slightly higher than the passive MLS group in the Recognition of Assumptions. It can be observed, further, that there is no significant difference between the group scores across the five components, considering that the $p$-values range from $p=.309$ to $p=.929$, all of which are greater than $p=.05$. These show that the active MLS group and the 
passive MLS group were comparable in critical thinking sub-skills prior to their participation in the study.

Table 6: Mann-Whitney $U$ test per component of the critical thinking inventory pre-test

\begin{tabular}{|c|c|c|c|c|c|c|c|}
\hline \multirow{2}{*}{$\begin{array}{c}C T \\
\text { Component }\end{array}$} & \multicolumn{2}{|c|}{ Active MLS } & \multicolumn{2}{|c|}{ Passive MLS } & \multirow[b]{2}{*}{$M-W U$} & \multirow[b]{2}{*}{$Z$} & \multirow[b]{2}{*}{$p$} \\
\hline & $\begin{array}{c}M n \\
(\operatorname{Max} .=60)\end{array}$ & $\begin{array}{l}\text { Mean } \\
\text { Rank }\end{array}$ & $\begin{array}{c}M n \\
(\operatorname{Max} .=60)\end{array}$ & $\begin{array}{l}\text { Mean } \\
\text { Rank }\end{array}$ & & & \\
\hline Inference & $31.3(52.2 \%)$ & 9.22 & $32.1(53.5 \%)$ & 9.78 & 38.0 & -.222 & .825 \\
\hline $\begin{array}{l}\text { Recognition of } \\
\text { Assumptions }\end{array}$ & $22.9(38.2 \%)$ & 9.61 & $20.8(34.7 \%)$ & 9.39 & 39.5 & -.089 & .929 \\
\hline Deduction & $24.3(40.5 \%)$ & 8.67 & $27.2(45.3 \%)$ & 10.33 & 33.0 & -.665 & .506 \\
\hline Interpretation & $27.7(46.2 \%)$ & 9.17 & $28.7(47.8 \%)$ & 9.83 & 37.5 & -.266 & .790 \\
\hline $\begin{array}{l}\text { Evaluation of } \\
\text { Arguments }\end{array}$ & $17.8(29.7 \%)$ & 8.22 & $22.7(37.8 \%)$ & 10.78 & 29.0 & -1.02 & .309 \\
\hline
\end{tabular}

4.2. Results of the Critical Thinking Inventory Post-test. The Preservice Teacher Critical Thinking Inventory in physics was administered again a day after the intervention as a post-test. Table 7 presents the mean and median group scores and standard deviations. Interestingly, the active MLS group incurred a higher overall mean score $(M n=241.8,80.6 \%)$ than the passive MLS group $(M n=214.1$, $71.4 \%)$. A lower standard deviation was also incurred by the active MLS group $(S D=12.7)$ than by the passive MLS group $(S D=23.4)$. This signifies that the scores of the participants exposed to the active MLS were closer than the scores of those exposed to the passive MLS.

Table 7: Post-test results for the overall critical thinking inventory

\begin{tabular}{lcccc}
\hline Test/Group & N & Md (Max.=300) & $\begin{array}{c}\text { Mn } \\
(\text { Max. }=300)\end{array}$ & SD \\
\hline Post-test & & & & \\
Active MLS & 9 & $246(82.0 \%)$ & $241.8(80.6 \%)$ & 12.7 \\
Passive MLS & 9 & $217(72.3 \%)$ & $214.1(71.4 \%)$ & 23.4 \\
$\quad$ Total & 18 & $239(79.7 \%)$ & $227.9(76.0 \%)$ & \\
\hline
\end{tabular}

To determine the effect of the intervention on the group's overall critical thinking, the Wilcoxon Signed Ranks test was utilized. The test compares the pre-test and post-test scores of both groups. It is shown in Table 8 that both the active MLS and passive MLS groups obtained significantly higher post-test scores $(p=.008)$ than their pre-test scores. This suggests that both the active MLS and the passive MLS can significantly improve the critical thinking of the preservice physics teachers.

Table 8: Wilcoxon Signed Ranks Test for the two groups in the overall critical thinking inventory

\begin{tabular}{cccc}
\hline \multicolumn{1}{c}{ Group } & $N$ & $Z$ & $p$ \\
\hline Active MLS & 9 & -2.67 & $.008^{* *}$ \\
Passive MLS & 9 & -2.67 & $.008^{* *}$ \\
\hline Note: ${ }^{*} p<.05 ;{ }^{* *} p<.01$ & & &
\end{tabular}

Further examination was done to probe significant differences in the effects of the two interventions on participants' critical thinking. The Mann-Whitney $U$ test, as shown in Table 9, revealed that the participants who were exposed to the active 
MLS obtained a significantly higher mean score than those who were exposed to the passive MLS, as indicated by a $\mathrm{p}$-value of $p=.007$. Moreover, a relatively high effect size of $r=.636$ had been established by the intervention between the two groups of participants. These connote that the active MLS is significantly better at developing the overall critical thinking of the preservice physics teachers than the passive MLS.

Table 9: Mann-Whitney $U$ test of the critical thinking inventory post-test

\begin{tabular}{|c|c|c|c|c|c|c|}
\hline Test/Group & $N$ & $\begin{array}{l}\text { Mean } \\
\text { Rank }\end{array}$ & $\begin{array}{c}\text { Mann- } \\
\text { Whitney } U\end{array}$ & $Z$ & $p$ & $r(E S)$ \\
\hline Post-test & & & \multirow[b]{2}{*}{10.00} & \multirow[b]{2}{*}{-2.70} & \multirow[b]{2}{*}{$.007^{* *}$} & \multirow[b]{2}{*}{.636} \\
\hline $\begin{array}{l}\text { Active MLS } \\
\text { Passive MLS }\end{array}$ & $\begin{array}{l}9 \\
9\end{array}$ & $\begin{array}{l}12.9 \\
6.11\end{array}$ & & & & \\
\hline
\end{tabular}

Note: ${ }^{*} p<.05 ;{ }^{* *} p<.01$

The post-test mean scores of the participants per component of the Critical Thinking Inventory are presented in Table 10. It must be noted that the active MLS group scored higher than the passive MLS group across all components, the score of which ranged from $75.55 \%$ up to $86.85 \%$, as opposed to $68 \%$ up to $76.30 \%$. This points out that the active MLS group performed better than the passive MLS group in all the sub-tests after the intervention.

Table 10: Post-test mean scores per critical thinking component

\begin{tabular}{lcc}
\hline \multicolumn{1}{c}{ Critical Thinking } & Active MLS & Passive MLS \\
\cline { 2 - 3 } \multicolumn{1}{c}{ Component } & Mn $($ Max. $=60)$ & Mn (Max. $=60)$ \\
\hline Inference & $52.11(86.85 \%)$ & $45.78(76.30 \%)$ \\
Recognition of & $45.33(75.55 \%)$ & $41.00(68.33 \%)$ \\
Assumptions & & \\
Deduction & $47.44(79.07 \%)$ & $42.11(70.18 \%)$ \\
Interpretation & $49.44(82.40 \%)$ & $41.56(69.27 \%)$ \\
Evaluation of Arguments & $47.44(79.07 \%)$ & $43.67(72.78 \%)$ \\
\hline
\end{tabular}

A comparison between the pre-test and post-test scores of each group per component was established through the Wilcoxon Signed Ranks Test. It can be seen in Table 11 that the p-values across all components are less than the .05 (i.e. $p=.008$ ) for both groups, implying that both groups obtained significantly higher scores in the post-test than in the pre-test of the critical thinking sub-tests. Further, it can be deduced that both the active MLS and the passive MLS are effective interventions in enhancing the critical thinking sub-skills of the preservice teachers.

Table 11: Wilcoxon Signed Ranks Test per component of the critical thinking inventory

\begin{tabular}{lcccc}
\hline \multicolumn{1}{c}{$\begin{array}{c}\text { Critical Thinking } \\
\text { Component }\end{array}$} & Group & $\boldsymbol{N}$ & $\boldsymbol{Z}$ & $\boldsymbol{p}$ \\
\hline Inference & Active MLS & 9 & -2.67 & $.008^{* *}$ \\
& Passive MLS & 9 & -2.67 & $.008^{* *}$ \\
\hline Recognition of & Active MLS & 9 & -2.67 & $.008^{* *}$ \\
Assumptions & & & -2.67 & $.008^{* *}$ \\
\hline
\end{tabular}




\begin{tabular}{lclll}
\hline Deduction & Active MLS & 9 & -2.67 & $.008^{* *}$ \\
& Passive MLS & 9 & -2.67 & $.008^{* *}$ \\
\hline Interpretation & Active MLS & 9 & -2.67 & $.008^{* *}$ \\
& Passive MLS & 9 & -2.67 & $.008^{* *}$ \\
\hline Evaluation of & Active MLS & 9 & -2.67 & $.008^{* *}$ \\
Arguments & & & -2.67 & $.008^{* *}$ \\
\hline
\end{tabular}

Note: ${ }^{*} p<.05 ;{ }^{* *} p<.01$

Table 12 exhibits the Mann-Whitney $U$ test analysis between the two groups of participants per component of the Preservice Teacher Critical Thinking Inventory. It can be reckoned that the Active MLS group obtained a significantly higher mean score than the passive MLS group in the Inference $(p=.024)$ and Interpretation components $(p=.003)$. No significant difference in the group scores was perceived in the Recognition of Assumptions, Deduction, and Evaluation of Arguments, since the $p$-values fall beyond the $p=.05$ level. These results imply that engaging in the active MLS can significantly improve the critical thinking skills of the preservice physics teachers, rather than the passive MLS, specifically on inferencemaking and interpreting information.

Table 12: Mann-Whitney $U$ test per critical thinking component for the post-test

\begin{tabular}{|c|c|c|c|c|}
\hline \multirow{2}{*}{$\begin{array}{l}\text { Critical Thinking } \\
\text { Component }\end{array}$} & \multirow{2}{*}{ Group } & \multicolumn{3}{|c|}{ Post-test } \\
\hline & & Mean Rank & $M-W U$ & $p$ \\
\hline \multirow[t]{2}{*}{ Inference } & Active MLS & 12.33 & \multirow{2}{*}{15.00} & \multirow{2}{*}{$.024^{*}$} \\
\hline & Passive MLS & 6.67 & & \\
\hline \multirow{2}{*}{$\begin{array}{l}\text { Recognition of } \\
\text { Assumptions }\end{array}$} & Active MLS & 7.28 & \multirow{2}{*}{20.50} & \multirow{2}{*}{.076} \\
\hline & Passive MLS & 11.72 & & \\
\hline \multirow[t]{2}{*}{ Deduction } & Active MLS & 11.61 & \multirow{2}{*}{21.50} & \multirow{2}{*}{.093} \\
\hline & Passive MLS & 7.39 & & \\
\hline \multirow[t]{2}{*}{ Interpretation } & Active MLS & 13.17 & \multirow{2}{*}{7.50} & \multirow{2}{*}{$.003^{* *}$} \\
\hline & Passive MLS & 5.83 & & \\
\hline \multirow{2}{*}{$\begin{array}{l}\text { Evaluation of } \\
\text { Arguments }\end{array}$} & Active MLS & 11.89 & \multirow{2}{*}{19.00} & \multirow{2}{*}{.056} \\
\hline & Passive MLS & 7.11 & & \\
\hline
\end{tabular}

Note: ${ }^{*} p<.05 ;{ }^{* *} p<.01$

\section{Discussion}

Findings of the study indicated the positive effects of both the active and passive MLS in enhancing overall critical thinking and its sub-skills in preservice physics teachers. These findings concur with the results of the study of Burroughs and Luebeck (2010), who proclaimed that Lesson Study allows the preservice teachers to act as critical thinkers and think like real teachers. It must be noted that the research participants worked collaboratively in preparing the instructional plans and materials; the exchange of thoughts and viewpoints is inevitable. Accordingly, the theory of adult learning asserts that establishing a cooperative milieu augments learning through varied networks (Knowles, 1973; 1984). In essence, the active and passive MLS are collaborative learning engagements that develop social skills (Mewald \& Mürwald-Scheifinger, 2019), and promote a collective sense of responsibility, powerful social interactions, and academic discourses (Cajkler et al., 2015; Cerbin \& Kopp, 2006; Hixon, 2009; Kolenda, 2007; Laal \& Laal, 2012). 
To explicate the assertion above, Dianne stated in an interview that working with her groupmates had helped to improve her instructional skills. She stated: “...it's very helpful that I have partners [groupmates] who help me, to give additional advices [pieces of advice], additional ideas for [my] lesson and [on] how to deliver the lesson." (Dianne)

In view of the aforementioned desired results, engaging in the active and passive MLS might serve as an excellent training ground for accelerating teaching performance considering that these forms of instructional approach demand insightful reflections and critical analysis of their thinking and teaching (Arsal, 2015, 2017; Hamzah et al., 2008). Likewise, the assessment of critical thinking through a content-based instrument such as the Preservice Teacher Critical Thinking Inventory in Physics permits a close examination of both critical thinking skills and content knowledge of the participants. Exposure of the preservice teachers to such an assessment tool brings Physics ideas in a different perspective, opening for more learning opportunities geared towards conceptual understanding in Physics (Buabeng et al., 2016).

Results further suggest that the Active MLS is more effective at enhancing overall critical thinking and its sub-skills, namely, inference and interpretation, than the Passive MLS. Cerbin and Kopp (2006) and Zhou and Xu (2017) have proclaimed that the collaborative preparation of instructional plans and materials, lesson implementations, and post-lesson discussions prompt the Lesson Study members to clarify inquiries and reservations, explore techniques and procedures, and reflect on all aspects of instruction. This alludes to the contention that one essential feature of collaborative learning is a receptive discourse that promotes articulation, scrutiny, and justification of viewpoints leading the learners to generate tailored conceptual frameworks (Laal \& Laal, 2012).

The higher level of critical thinking of the Active MLS group than the Passive MLS group may also be attributed to the "internal pressure" incited by the lesson implementations with their contemporaries serving as "students" and with the presence of the subject teacher and researcher (Cavin, 2007; Cerbin \& Kopp, 2006). The active MLS members were compelled to keenly examine lesson implementation procedures, bearing in mind that their audience had comparable or even greater knowledge, skills, and faculties than they themselves. In an interview, Robert divulged his anxiety when he implemented his first lesson:

Robert: Yes, Sir. Based on what we experienced as a teacher, we felt conscious of the presence of our classmates. They already know the concepts, so we tend to be affected in our demo, Sir. We also tend to be conscious of what we say. We are intimidated by our classmates ... and by your presence as well, Sir.

Researcher: Okay. So, you get intimidated?

Robert: Yes, Sir. That is why we try our best in our teaching.

Alexa expressed a similar impression in one of her journal entries.

....Two days from now, our group will teach the next topic. We are nervous because Rina's group has done great [in their demonstration 
teaching]. We plan to use computerized [digital] representations because they [classmates] enjoy the discussion and activities... (Alexa)

The lesson implementations prompted the active MLS group to embark on technology-based pedagogies such as the incorporation of digital representations. They utilized diagrams, animations, video clips, and simulations of scientific concepts, principles, and processes. The interaction with media-aided representations fosters critical analysis competencies and engagements with critical thinking (Barlow et al., 2013; Quinnell et al., 2020). The preparation, implementation, and reflection phases of the active MLS allowed the group members to scrutinize, assess, and revise the instructional aids that complement teaching methodologies.

\section{Conclusion and Recommendation}

The findings of this study suggest that both the active and passive MLS are effective in developing the critical thinking of the preservice physics teachers. It further has been confirmed that active MLS is more effective at developing overall critical thinking and sub-skills inference and interpretation than passive MLS. The findings of this study suggest that preservice teacher education may be enriched by integrating active and passive MLS in the teacher education curriculum. The affordances of these two forms of microteaching lesson study (MLS) can address the need to scaffold preservice teachers' instructional competencies (Cavanagh et al., 2019) which the conventional individualistic instructional approach does not warrant, particularly the development of critical thinking.

It is, hence, recommended that preservice teachers be exposed to these two instructional approaches, especially to the active MLS. Conducting similar studies involving more participants may be endeavoured to reinforce positive influences of the intervention. Digital instructional aids and tools also may be provided to these future participants to maximize learning engagements. Likewise, contentoriented critical thinking assessment tools like the PTCTI may be developed, evaluated, and utilized in research to supplement existing knowledge on the critical thinking construct. Finally, the integration of computer-generated representations in collaborative instructional designs is encouraged not only to capture interest but also to stimulate critical analysis and higher-order thinking (Ozmantar et al., 2010).

\section{Acknowledgments}

The author acknowledges the professional and financial support of the Leyte Normal University (LNU) through the LNU Faculty and Staff Development Program (FSDP) and the Dissertation Grant of the Commission on Higher Education in the completion of this academic endeavour. Profound gratitude is hereby conveyed.

Likewise, the author expresses earnest appreciation to the academic pillars of the UP College of Education, UP NISMED, UP Open University, and the National Institute of Physics for the insightful assistance in scaffolding the integrity of this paper. 


\section{References}

Akdere, N. (2012). Turkish preservice teachers' critical thinking levels, attitudes and selfefficacy beliefs in teaching for critical thinking. [Thesis, Middle East Technical University, Ankara]. http:/ /etd.lib.metu.edu.tr/upload/12614436/index.pdf

Akkus, H., \& Üner, S. (2017). The effect of microteaching on preservice chemistry teachers' teaching experiences. Cukurova University Faculty of Education Journal, 46 (1), 202230. https://doi.org10.14812/cuefd.309459

Akyuz, H., \& Samsa, S. (2009). Critical thinking skills of preservice teachers in the blended learning environment. International Journal of Human Sciences, 6(2), 538-550.

Arsal, Z. (2015). The effects of microteaching on the critical thinking dispositions of preservice teachers. Australian Journal of Teacher Education, 40(3), 140-153. http://dx.doi.org/10.14221/ajte.2014v40n3.9

Arsal, Z. (2017). The impact of inquiry-based learning on the critical thinking dispositions of preservice science teachers. International Journal of Science Education, 39(10), 1326-1338.

Battelle for Kids (2019). Framework for 21st century learning: Definitions. http://static.battelleforkids.org/documents/p21/P21_Framework_DefinitionsB FK.pdf

Barlow, A. T., McCrory, M. R., \& Blessing, S. (2013). Classroom observations and reflections: Using online streaming video as a tool for overcoming barriers and engaging in critical thinking. International Journal of Education in Mathematics, Science and Technology, 1(4), 238-258.

Barrett, D., Riggs, L., \& Ray, J. (2013). Teachers' collaborative use of the lesson study approach to foster student achievement in geometry. International Journal of Social Sciences \& Education, 3(4), 1188-1192.

Behar-Horenstein, L., \& Niu, L. (2011). Teaching critical thinking skills in higher education: A review of the literature. Journal of College Teaching \& Learning, 8(2), 25-41.

Buabeng, I., Conner, L., \& Winter, D. (2016). Physics teachers' views on their initial teacher education. Australian Journal of Teacher Education, 41(7), 36-55. http://dx.doi.org/10.14221/ajte.2016v41n7.3

Buchard, J., \& Martin, D. (2017). Lesson study... and its effects. Hellenic Journal of Research Education, Special Issue, 1-15. http://dx.doi.org/10.12681/hjre.14809

Buckley, S. (2012). The role of computational thinking and critical thinking in problem solving in a learning environment. European Conference on e-Learning (pp. 63-70). Kidmore End, United Kingdom: Academic Conferences International Limited.

Burroughs, E., \& Luebeck, J. (2010). Preservice teachers in mathematics lesson study. The Mathematics Enthusiast, 7(2), 391-400.

Cajkler, W., Wood, P., Norton, J., Pedder, D., \& Xu, H. (2015). Teacher perspectives about lesson study in secondary school departments: A collaborative vehicle for professional learning and practice development. Research Papers in Education, 30(2), 192-213.

Cavanagh, M., Barr, J., Moloney, R., Lane, R., Hay, I., \& Chu, H. (2019). Preservice teachers' impact on student learning: Planning, teaching, and assessing during professional practice. Australian Journal of Teacher Education, 44(2), 66-81.

http://dx.doi.org/10.14221/ajte.2018v44n2.5

Cavin, R. (2007). Developing technological pedagogical content knowledge in preservice teachers through microteaching lesson study [Doctoral Dissertation, Florida State University]. Ann Arbor, MI: ProQuest Information and Learning Center/UMI. 
Cerbin, W., \& Kopp, B. (2006). Lesson study as a model for building pedagogical knowledge and improving teaching. International Journal of Teaching and Learning in Higher Education, 18(3), 250-257.

Chen, X., \& Zhang, Y. (2019). Typical practices of lesson study in East Asia. European Journal of Education, 54(2), 189-201.

Chew, C., \& Lim, C. (2013). Developing preservice teachers' technological pedagogical content knowledge for teaching mathematics with the geometer's sketchpad through lesson study. Journal of Education and Learning, 2(1), 1-8.

Danday, B. (2019). Active vs. passive microteaching lesson study: Effects on pre-service teachers' technological pedagogical content knowledge. International Journal of Learning, Teaching, and Educational Research, 18(6). 181-200. https://doi.org/10.26803/ijlter.18.6.11

Elipane, L. (2012). Integrating the essential elements of lesson study in preservice mathematics teacher education [Doctoral dissertation, Copenhagen University].

Ennis, R. (2009). An annotated list of critical thinking tests. https://www.academia.edu/34209488/AN_ANNOTATED_LIST_OF_CRITICA L_THINKING_TESTS

Facione, P. (1998). Critical thinking: A statement of expert consensus for purposes of educational assessment and instruction. Executive Summary "The Delphi Report". https://www.insightassessment.com/wp-content/uploads/ia/pdf/DEX-2014reprinting.pdf

Facione, P. (2020). Critical thinking: What it is and why it counts (2020 ed.)., Hermosa Beach, CA: Measured Reasons LLC.

Facione, P., \& Facione, N. (2011). The holistic critical thinking scoring rubric - HCTSR: A tool for developing and evaluating critical thinking. San Jose, CA: The California Academic Press / Insight Assessment.

Facione, P., Facione, N., \& Gittens, C. A. (2020). What the critical thinking data tell us. Hermosa Beach, CA: Measured Reasons LLC/Insight Assessment.

Fernandez, C. (2002). Learning from Japanese approaches to professional development: The case of lesson study. Journal of Teacher Education, 53(5), 393-405.

Gadzella, B., Stacks, J., Stephens, R., \& Masten, W. (2005). Watson-Glaser critical thinking appraisal, form-S for education majors. Journal of Instructional Psychology, 32(1), 912.

Gashan, A. (2015). Exploring Saudi preservice teachers' knowledge of critical thinking skills and their teaching perceptions. International Journal of Education $\mathcal{E}$ Literacy Studies, 3(1), 26-33.

Glaser, E. (1941). An experiment in the development of critical thinking. New York: Teachers College, Columbia University.

Goyak, A. (2009). The effects of cooperative learning techniques on perceived classroom environment and critical thinking skills of preservice teachers [Doctoral dissertation, Liberty University]. Ann Arbor, MI: ProQuest LLC/UMI.

Grosser, M., \& Nel, M. (2013). The relationship between the critical thinking skills and the academic language proficiency of prospective teachers. South African Journal of Education, 33(2), 1-17.

Gurl, T. (2009). An analysis of an adaptation of lesson study with preservice secondary mathematics teachers [Doctoral dissertation, Columbia University]. Ann Arbor, MI: ProQuest LLC/UMI.

Gutierez, S. (2015). Collaborative professional learning through lesson study: Identifying the challenges of inquiry-based teaching. Issues in Educational Research, 25(2), 118134. 
Hamzah, S. G., Mohamad, H., \& Ghorbani, M. R. (2008). Excellent teachers' thinking model: Implications for effective teaching. Australian Journal of Teacher Education, 33(4), 11-27. http://dx.doi.org/10.14221/ajte.2008v33n4.2

Hixon, M. (2009). Lesson study: A proposed intervention for professional development and student achievement [Doctoral dissertation, Walden University]. Ann Arbor, MI: UMI Dissertation Publishing, ProQuest LLC.

Jatmiko, B., Prahani, B. K., Munasir, Supardi, Z. A. I., Wicaksono, I., Erlina, N., \& Zainuddin. (2018). The comparison of OR-IPA teaching model and problembased learning effectiveness to improve critical thinking skills of preservice physics teachers. Journal of Baltic Science Education, 17(22), 300-319.

Kolenda, R. (2007). Japanese lesson study, staff development, and science education reform: - The Neshaminy story. Science Educator, 16(1), 29-33.

Knowles, M. (1973). The adult learner: A neglected species. Houston: Gulf Publishing.

Knowles, M. (1984). The adult learner: A neglected species (3rd ed.). Houston, TX: Gulf Publishing.

Laal, M., \& Laal, M. (2012). Collaborative learning: What is it? Procedia - Social and Behavioral Sciences 31, 491-495.

Lewis, C. (2002). Does lesson study have a future in the United States? Nagoya Journal of Education and Human Development 1, 1-23.

Lewis, C., Perry, R., \& Hurd, J. (2009). Improving mathematics instruction through lesson study: A theoretical model and North American case. Journal of Mathematics Teacher Education, 12, 285-304. doi:10.1007/s10857-009-9102-7

Lewis, C., Perry, R., \& Murata, A. (2006). How should research contribute to instructional improvement? The case of lesson study. Educational Researcher, 35, 3-14. https://doi.org/10.3102/0013189X035003003

Lucenario, J., Yangco, R., Punzalan, A., \& Espinosa, A. (2016). Pedagogical content knowledge-guided lesson study: Effects on teacher competence and students' achievement in chemistry. Education Research International, 2016, 1-9.

McDowell, A. (2010). Preservice teachers' use of lesson study in teaching nature of science [Doctoral dissertation, Georgia State University]. http:/ / scholarworks.gsu.edu/cgi/viewcontent.cgi?article=1064\&context=msit_ diss

Meister, D. (2011, February 15). Preservice teachers' impact on student learning: Threeyear study of the impact on student learning project [Paper presentation]. Association of Teacher Educators Annual Conference, Orlando, Florida. http:// files.eric.ed.gov/fulltext/ED524510.pdf

Mewald, C., \& Mürwald-Scheifinger, E. (2019). Lesson study in teacher development: A paradigm shift from a culture of receiving to a culture of acting and reflecting. European Journal of Education, 54(2), 218-232.

Nilson, C., Fetherston, C. M., McMurray, A., \& Fetherston, T. (2013). Creative arts: An essential element in the teacher's toolkit when developing critical thinking in children. Australian Journal of Teacher Education, 38(7), 1-17. http://dx.doi.org/10.14221/ajte.2013v38n7.4

Ozmantar, M., Akkoc, H., Bingolbali, E., Demir, S., \& Ergene, B. (2010). Preservice mathematics teachers' use of multiple representations in technology-rich environments. Eurasia Journal of Mathematics, Science \& Technology Education, 6(1), 19-36.

Qing, Z., Jing, G., \& Yan, W. (2010). Promoting preservice teachers' critical thinking skills by inquiry-based chemical experiment. Procedia Social and Behavioral Sciences, 2, 4597-4603. 
Tican, C., \& Taspinar, M. (2015). The effects of reflective thinking-based teaching activities on preservice teachers' reflective thinking skills, critical thinking skills, democratic attitudes, and academic achievement. The Anthropologist 20(1,2), 111120. http://dx.doi.org/10.1080/09720073.2015.11891730.

Quinnell, L., Iyer, R. \& Ewing, B. (2020). Preservice teachers as document detectives. Australian Journal of Teacher Education, 45(6). http://dx.doi.org/10.14221/ajte.2020v45n6.2

Remesh, A. (2013). Microteaching: An efficient technique for learning effective teaching. Journal of Research in Medical Sciences, 18, 158-63.

Sensibaugh, C. (2015). Defining and assessing problem solving across a biochemistry curriculum [Doctoral dissertation, University of New Mexico]. Ann Arbor, MI: ProQuest LLC.

Sentumbwe, D. (2018). Student-teachers' experiences of microteaching on an economics methods course. African Research Review, 12(2), 101-108. http://dx.doi.org/10.4314/afrrev.v12i2.10.

Sulaiman, F. (2013). The effectiveness of PBL online on preservice science. Wudpecker Journal of Educational Research, 2(6), 086 - 096.

Teele, S., Maynard, D. \& Marcoulides, G. (2015). The lesson study process: - An effective intervention to reduce the achievement gap. US-China Education Review, 5(4), 229243.

Tseng, M.-H. (2008). Data-driven problem solving and students' critical thinking in a problembased learninng environment. Ann Arbor, MI: ProQuest LLC/UMI.

Williams, R. (2005). Targeting critical thinking within teacher education: The potential impact on society. The Teacher Educator, 40(3), 163-187.

Zhou, G. \& Xu, J. (2017). Microteaching lesson study: An approach to prepare teacher candidates to teach science through inquiry. International Journal of Education in Mathematics, Science and Technology, 5(3), 235-247. DOI:10.18404/ijemst.296039 
Appendix 1: Sample Items of the Research Instrument

Preservice Teacher Critical Thinking Inventory in Physics

Name:

Date:

Course/Year/Section: Specialization:

\section{GENERAL INSTRUCTIONS:}

There are five components of this test - Inference, Recognition of Assumptions, Deduction, Interpretation, and Evaluation of Arguments.

Each subtest or component consists of statements with proposed inferences, assumptions, conclusions or arguments. Specific instructions are provided in each subtest. Read carefully and follow instructions correctly. You are REQUIRED to explain or state your reasons for your choice of answer for each item. Limit your explanation to 1 - 3 sentences only. You have a maximum of one (1) hour and thirty (30) minutes to finish this test.

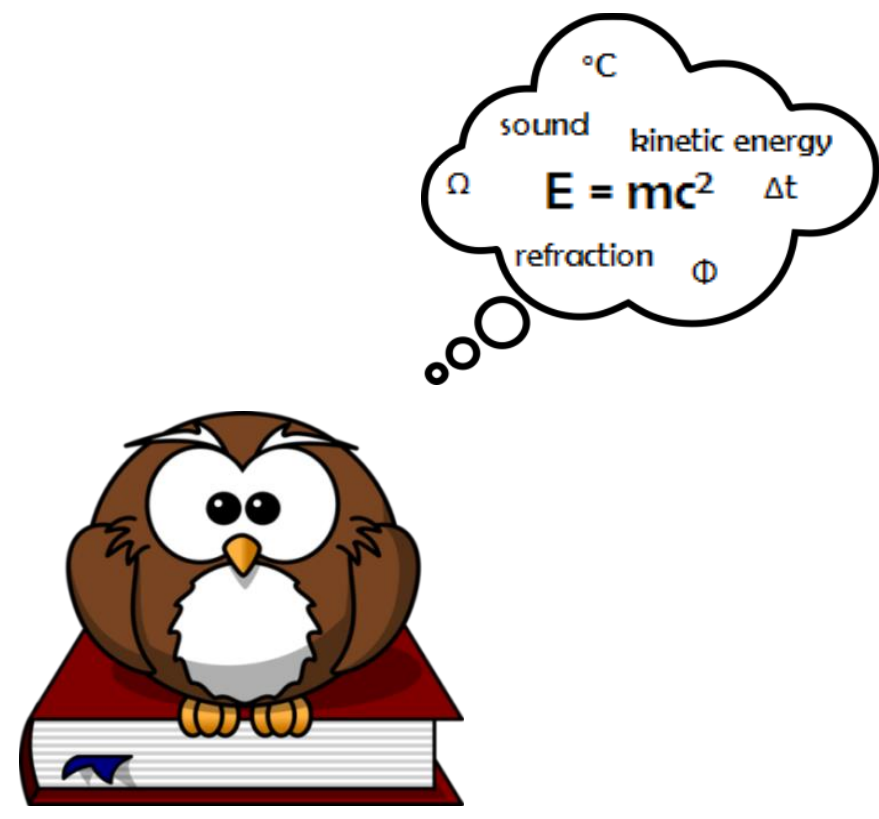

STOP!

DO NOT TURN TO THE NEXT PAGE UNLESS YOU ARE TOLD TO DO SO. 


\section{TEST II: RECOGNITION OF ASSUMPTIONS}

Directions: There are five statements or scenarios in this test. Each statement is followed by suggested assumptions. Encircle 'YES' in the corresponding item number on your answer sheet if you believe that the given assumption is correct. If you think the assumption is not necessarily correct, encircle 'NO'. Give a concise explanation of your answer on the space provided.

Statement II-2: Two charges at rest, $\mathrm{q}_{1}$ and $\mathrm{q}_{2}$, lie behind a rectangular cardboard. An electric field pattern is observed as shown in the figure below.

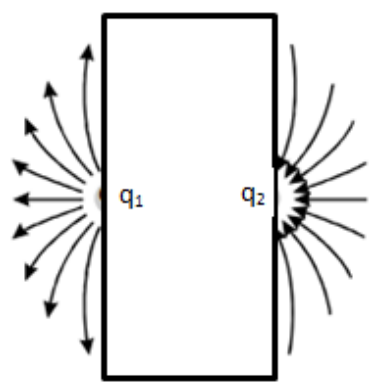

Proposed Assumptions:

16. The charges are the same and are equal in magnitude.

Explain your answer:

17. Charge $\mathrm{q}_{1}$ is positive while charge $\mathrm{q}_{2}$ is negative.

YES

NO

Explain your answer: 